\title{
Primary Cardiac Angiosarcoma: A Case Report
}

\section{Primer Kardiyak Anjiosarkoma: Bir Olgu Sunumu}

\author{
Ayşe Gök Durnalı ${ }^{1}$, Ayşe Yüksel ${ }^{2}$, Muzaffer Bedri Altundağ ${ }^{3}$, Murat Vural ${ }^{4}$, Berna Öksüzoğlu ${ }^{1}$, Necati \\ Alkış
}

${ }^{1}$ Dr.A. Y. Ankara Onkoloji Eğitim ve Araştırma Hastanesi, Tıbbi Onkoloji Kliniğgi, Ankara, Türkiye

${ }^{2}$ Ankara Onkoloji Eğitim ve Araştırma Hastanesi, Kardiyoloji Kliniği, Ankara, Türkiye

${ }^{3}$ Ankara Onkoloji Eğitim ve Araştırma Hastanesi, Radyasyon Onkolojisi Kliniği, Ankara, Türkiye

${ }^{4}$ Ankara Numune Eğitim ve Araştırma Hastanesi, Radyoloji Kliniği, Ankara, Türkiye

Dergiye Ulaşma Tarihi:26/02/2015 Dergiye Kabul Tarihi:28/05/2015 Doi: 10.5505/aot.2015.92400

\section{ÖZET}

Primer kardiyak anjiosarkoma, kötü prognozlu nadir bir hastalıktır. Açık kardiyak cerrahi operasyon olan ve sağ atriumda kardiyak anjiosarkoma tanısı alan 34 yaşında erkek hasta tıbbi onkoloji bölümüne başvurdu. Tümörün tam küratif rezeksiyonu mümkün olmamıştı ve hastaya postoperatif dönemde 6 siklus kombinasyon kemoterapi rejimi (doksorubisin ve mesna korumasıyla ifosfamid) verildi. Hastada 8 ay boyunca stabil hastalık mevcuttu ve progresyon sonrasında ikinci sıra kemoterapi (paklitaksel) başlandı, ancak hasta tanıdan 15 ay sonra kaybedildi. Kardiyak anjiosarkoma olgularının çoğunda küratif rezeksiyonlar mümkün olmadığından daha ileri tedavi seçeneklerine son derece ihtiyaç vardır.

Anahtar Kelimeler: Kardiyak anjiosarkoma, Kemoterapi

\begin{abstract}
Primary cardiac angiosarcoma is a rare disease with poor prognosis. A 34-year-old male patient who underwent an open cardiac surgery and diagnosed as cardiac angiosarcoma on the right atrium was admitted to the medical oncology department. Complete curative resection of the tumor was not possible and postoperatively 6 cycles of combination chemotherapy regimen (ifosphamide with mesna protection and doxorubicin) was given. Patient had stable disease for 8 months, and after progression a second-line chemotherapy (paclitaxel) was started but he died after 15 months of diagnosis. Since curative resections are not possible in most of the cardiac angiosarcoma cases, further treatment options are desperately needed.
\end{abstract}

Key words: cardiac angiosarcoma, chemotherapy

\section{Introduction:}

Most of the malignant neoplasms located in the heart are metastatic tumors. Primary cardiac tumors are quite rare, and only $25 \%$ of them are malignant $(1,2)$. One of the malignant primary neoplasm of the heart, namely cardiac angiosarcoma originates from the mesenchymal tissue and endothelial subepicardium. It occurs more frequently in young middle-aged patients and its prognosis is very poor $(3,4)$. We have reported a patient with this disease and our treatment outcomes.

\section{Case Report:}

A 34-year-old man was admitted to the medical oncology department with the diagnosis of cardiac angiosarcoma. In his past history, approximately one month ago, he was admitted to emergency department with chest pain, massive pleural effusion was detected on chest X-ray, and chest computerized tomography (CT) showed a mass in the right atrium. The chest tube was inserted and he underwent an open cardiac surgery. On exploration, pericardium was sticky and enclosed by vascular structures, there was a mass with irregular borders on the right atrium extending to the right ventricle, and invasion to the right pleura. Since complete curative resection was not possible, partial resection was undertaken. Pathological examination of resected material was reported as welldifferentiated angiosarcoma with vascular invasion, $4 \times 3 \mathrm{~cm}$ in size, and there was 9 mitosis per 10 high power field (HPF) and 
eventually surgical margins were tumorpositive.

Cardiac magnetic resonance imaging (MRI), taken after admission to medical oncology department, revealed a mass, $81 \times 55 \mathrm{~mm}$ in size, invading the anterior wall of right ventricle, protruding into the cavity of right ventricle with the suspicion of invasion to tricuspid valve and right atrium and aorta (Figure 1).

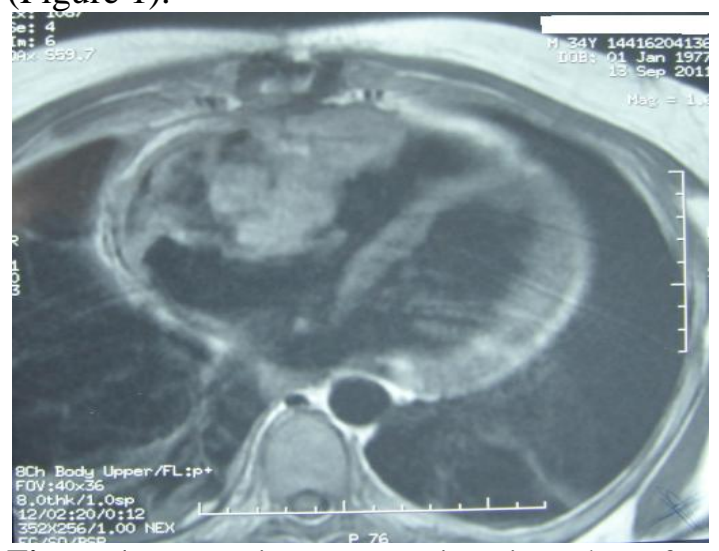

Figure 1: Magnetic resonance imaging taken after cardiac surgery revealed a mass, $81 \times 55 \mathrm{~mm}$ in size, invading the anterior wall of right ventricle.

Transthoracic echocardiography confirmed a semi mobile mass $50 \times 40 \mathrm{~mm}$ in size in the right atrium (Figure 2).

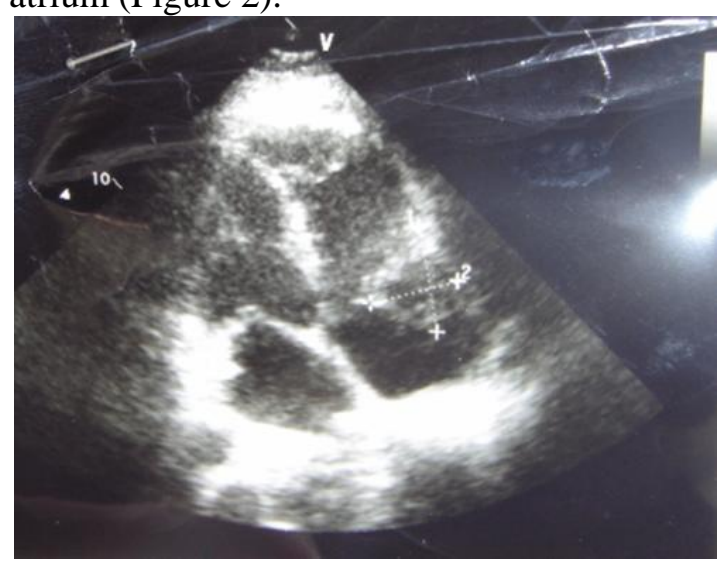

Figure 2: Transthoracic echocardiography showed a semi mobile mass $50 \times 40 \mathrm{~mm}$ in size in the right atrium

Abdominal ultrasonography was normal. A combination chemotherapy regimen used for other soft tissue sarcomas (ifosphamide $1800 \mathrm{mg} / \mathrm{m} 2 /$ day on $1-5$ days, with mesna protection, doxorubicin $60 \mathrm{mg} / \mathrm{m} 2 /$ day on day 1 , every 3 weeks), was started, and after the 1 st cycle, febrile neutropenia developed and chemotherapy doses were reduced by $20 \%$ at the following cycles. After 3 cycles of chemotherapy, there was a minimal regression on MRI findings and 3 more cycles were given. After 6 cycles, MRI and echocardiography revealed stable disease. Positron Emission Tomography (PET-CT) showed increased uptake of fluorodeoxyglucose only on right ventricular region. He was consulted to the heart surgery clinics for a second operation, however no more curative operation was considered to be possible. He was consulted with the radiotherapy clinics and radiotherapy was not indicated. About 5 months later, there was progression on cardiac MRI findings and chest CT showed metastatic nodules, $2 \mathrm{~cm}$ in diameter. With these findings second line chemotherapy (paclitaxel $175 \mathrm{mg} / \mathrm{m} 2 /$ day on day 1 , every 21 days) was started. After 3 cycles of paclitaxel chemotherapy, minimal regression was achieved, but after 6 cycles, clinical findings and imaging findings showed progression. Due to cardiac and respiratory failure, the patient died 45 days after the last chemotherapy cycle and 15 months after the initial diagnosis.

\section{Discussion:}

Primary cardiac angiosarcoma is seen infrequently, accounting for less than $10 \%$ of all primary cardiac tumors (5). It is seen mostly in right side of the heart and in young to middle-aged patients $(3,4)$. Symptoms vary according to the size and site of the tumor: chest pain, cough, syncope, dyspnea, lung edema, arrhythmia, peripheral edema, dizziness are the most common symptoms $(3,4,6,7,8)$. Transthoracic echocardiography and computed tomography (CT) are the useful tools for initial evaluation and suggestion of diagnosis, and MRI is helpful in preoperative differential diagnosis $(8,9)$. Diagnosis of cardiac angiosarcoma is often confirmed by the resection of the tumor. Because of the fragility of the tumor, myocardial biopsy is not recommended. In the presented case, CT was used for the initial evaluation; and cardiac MRI and echocardiography for the evaluation of residual tumor and chemotherapy responses. Because of the rarity of this disease, there has been no standard treatment guideline. If possible, extensive surgical resection of tumor is considered as the best curative management $(10,11)$. In some cases, radiotherapy after surgery was reported to improve outcomes 
$(2,10)$. There are insufficient data about the role of adjuvant chemotherapy. Chemotherapy regimens containing doxorubicin, ifosphamide, cisplatin and paclitaxel have been tried $(6,12,13,14)$. For advanced disease doxorubicin and weekly paclitaxel seem to provide some improvement in progression free survival (14). Several phase II trials have been published investigating vascular endothelial growth factor receptor (VEGFR) tyrosine kinase inhibitors such as sorafenib, imatinib, pazopanib, sunitinib and anti- vascular endothelial growth factor (VEGF) antibody, bevacizumab, demonstrated that some angiosarcoma patients had response or durable disease stabilization on these agents $(14,15$, 16) One of these phase II studies, sorafenib showed limited antitumor activity in pretreated patients only, for both visceral and superficial angiosarcoma, with short duration of tumor control (16). Further studies are needed to confirm these findings and to identify which patients will benefit from these agents.

Whatever the chosen treatment modality, the prognosis of cardiac angiosarcoma is poor and the median survival is between 3 to 12 months. Surgical excision of the tumor may be associated with better survival increasing up to 21 months (10). If surgical resection is not possible, median survival is approximately 6 months $(7,17)$. In one case report of a metastatic patient, multimodality palliative treatment with neoadjuvant and adjuvant chemotherapy and surgery improved survival (18). The patient presented herein had minimal symptomatic disease for about 8 months with multimodality treatment including incomplete resection and chemotherapy.

In conclusion, primary cardiac angiosarcoma is a rare and aggressive tumor with poor prognosis. For treatment options; surgical resection should be considered first and chemotherapy and radiotherapy may be indicated for palliative purposes.

\section{Conflict of interest: None}

\section{References:}

1. Reynen K: Frequency of primary tumors of the heart. Am J Cardiol. 1996; 77: 107
2. Moggio RA, Pucillo AL, Schechter AG, Pooley RW, Sarabu MR, Reed GE: Primary cardiac tumors: diagnosis and management in 14 cases. NY State Med J Med. 1992; 92: 48-52

3. Naka N, Ohsawa M, Tomita Y, Kanno H, Uchida A, Aozasa Kl: Angiosarcoma in Japan: a rewiev of 99 cases. Cancer. 1995;75: 989-996

4. Ge Y, Ro JY, Kim D,et al. Clinicopathologic and immunohistochemical characteristics of adult primary cardiac angiosarcomas: analysis of 10 cases. Ann Diagn Pathol. 2011;15(4): 262-7

5. Dennig K, Lehmann G, Richter T: An angiosarcoma in the left atrium. N Engl J Med. 2000;342:443-444.

6. Pezzuto A, Gencarelli G, Martone L, Bruno P, Mariotta S: Primary cardiac angiosarcoma in a young women. Case Rep Oncol. 2010;3:24-29

7. Gong Y, Hong T, Chen M, Huo Y: A right heart angiosarcoma with rapidly progressing hemorrhagic pericardial effusion. Intern Med. 2011;50: 455-458

8. Castilla-Cabanes E, Pascual-Calleja I, RoncalesGarcia Blanco F, del Rio-Ligorit A: Clinical variations of cardiac sarcoma. Rev Esp Cardiaol. 2009;62: 823-824

9. Di Bela G, Gaeta M, Patane L, Lentini S: Tissue characterization of a primary cardiac angiosarcoma using magnetic resonance imaging. Letter to editor. Rev Esp Cardiol. 2010; 63(11): 1382-3

10. Poole GV, Meredith JW, Brejer R: Surgical implications in malignant cardiac disease. Ann Thor Surg. 1983;36: 484-491

11. Erpolat OP, Icli F, Doğan OV, et al. Primary cardiac angiosarcoma: a case report. Tumori. 2008;94: 892897

12. Sarrjeant JM, Butany J, Cusimano RJ: Cancer of the heart: epidemiology and management of primary tumors and metastasis. Am J Cardiovasc Drugs. 2003;3: 407-421

13. Ram Prabu MP, Thulkar S, Ray R, Bakhshi S. Primary cardiac angiosarcoma with good response to paclitaxel. Letter to editor. J Thorac Oncol. 2011;6(10): 1778-1779

14. Penel N, Marréaud S, Robin YM, Hohenberger P. Angiosarcoma: state of the art and perspectives. Crit Rev Oncol Hematol. 2011 Nov;80(2):257-63

15. Park MS, Ravi V, Araujo DM. Inhibiting the VEGFVEGFR pathway in angiosarcoma, epithelioid hemangioendothelioma and hemangiopericytoma / solitary fibrous tumor. Curr Opin Oncol. 2010 Jul;22(4):351-5

16. Ray-Coquard I, Italiano A, Bompas E, et al. Sorafenib for patients with advanced angiosarcoma: a phase II Trial from the French Sarcoma Group (GSF/GETO). Oncologist 2012;17(2):260-6

17. Simpson L, Kumar SK, Okuno SH, et al Malignant primary cardiac tumors: review of a single institution experience. Cancer. 2008;112: 2440-2446.

18. Pigott C, Welker M, Khosla P, Higgins RS: Improved outcome with multimodality therapy in primary cardiac angiosarcoma. Nat Clin Pract Oncol. 2008;5: 112-115 